\title{
Reaction Characteristics and Existing Form of Phosphorus during Coal-Based Reduction of Oolitic Iron Ore
}

\author{
Jianping Jin, Wentao Zhou * ${ }^{\mathbb{C}}$, Yongsheng Sun, Yuexin Han and Yanjun Li \\ College of Resources and Civil Engineering, Northeastern University, Shenyang 110819, China; \\ jin20030944@126.com (J.J.); yongshengsun@mail.neu.edu.cn (Y.S.); dongdafulong@mail.neu.edu.cn (Y.H.); \\ liyanjun@mail.neu.edu.cn (Y.L.) \\ * Correspondence: zhou13840541273@163.com; Tel.: +024-83687120
}

check for updates

Citation: Jin, J.; Zhou, W.; Sun, Y.; Han, Y.; Li, Y. Reaction Characteristics and Existing Form of Phosphorus during Coal-Based Reduction of Oolitic Iron Ore. Minerals 2021, 11, 247. https://doi.org/10.3390/ $\min 11030247$

Academic Editor: Mark I. Pownceby

Received: 3 February 2021

Accepted: 23 February 2021

Published: 26 February 2021

Publisher's Note: MDPI stays neutral with regard to jurisdictional claims in published maps and institutional affiliations.

\begin{abstract}
It is particularly significant to investigate the reduction behavior and existing form of phosphorus in metal and slag phase during coal-based reduction for the efficient development and utilization of high-phosphorus oolitic hematite. The reduction behavior of phosphorus minerals and their existing form in the metal and slag phase during the coal-based reduction of high phosphorus oolitic hematite were systematically investigated using HSC software simulation, thermodynamic calculation, X-ray diffraction (XRD), scanning electron microscopy (SEM), and energy-dispersive spectrometry (EDS). The results show that after $\mathrm{Fe}_{2} \mathrm{O}_{3}$ was reduced to metal iron, the reduction of apatite was promoted by providing the most inclined enrichment site of phosphorus (metallographic phase). Phosphorus existed mainly in two forms in the metal phase-one was in the form of $\mathrm{Fe}_{3} \mathrm{P}$ compound at the boundary of the metal phase, and the other was in the form of solid solution in the metal iron. There were two forms of phosphorus in the slag phase-one was incompletely reacted apatite, and the other was formed as $\mathrm{CaO}-\mathrm{SiO}_{2}-\mathrm{P}_{2} \mathrm{O}_{5}$ solid solution. In the early stage of coal-based reduction, phosphorus in the slag phase mainly existed in the form of apatite, while in the later stage, it mainly existed in the form of $\mathrm{CaO}-\mathrm{SiO}_{2}-\mathrm{P}_{2} \mathrm{O}_{5}$ solid solution.
\end{abstract}

Keywords: high phosphorus oolitic hematite; coal-based reduction; phosphorus reaction behavior; existing form; metal and slag phase

\section{Introduction}

Despite the abundant reserves of iron ore resources in China, the overall iron ore is characterized by the behavior of low grade, fine grain size, and high impurities, resulting in the situation of importing large quantities of iron ore from abroad and the unavailability of domestic resources for many years [1-4]. Oolitic hematite ore with a total reserve of 3.72 billion tons has been unable to be exploited and utilized on a large scale due to its complex characteristics, causing a great waste of resources [5,6]. Since the 1930s, scholars at home and abroad have made many explorations and studies on the beneficiation of high phosphorus oolitic hematite. However, due to its high phosphorus content, fine size of iron ore, and complex mineral composition, it is impossible for traditional single mineral processes such as gravity separation, magnetic separation, and flotation (including positive flotation and reverse flotation) to beneficiate effectively and independently to meet industrial needs due to the limitations of their own processes [7-11]. Therefore, scholars at home and abroad try to use a combined separation process to treat oolitic hematite. Many research institutes adopt high-intensity magnetic-reverse flotation, roasting-magnetic separation, and roasting-magnetic separation-reverse flotation processes to study high-phosphorus oolitic hematite. However, many tests show that these processes cannot achieve satisfactory results in both iron concentrate grade and recovery rate, and these processes cannot effectively control the trend of phosphorus and achieve the comprehensive utilization of phosphorus [12-15]. Therefore, in order to realize the comprehensive utilization of 
high phosphorus oolitic hematite, the combined treatment of beneficiation and metallurgy should be more promising [16-19].

Due to the traditional beneficiation method is not effective for the treatment of high phosphorus oolitic hematite, researchers break through the traditional beneficiationsintering-smelting process and innovatively adopt coal-based reduction technology to treat complex refractory ores such as high phosphorus oolitic hematite [20-22]. Coal-based reduction technology refers to the process of reducing complex refractory iron ore, which cannot be directly used as blast furnace raw material, to metal iron at a higher temperature, having a stronger reduction atmosphere than magnetization roasting and making metal iron grow into certain size iron particles. The coal-based reduction is a reduction state between direct reduction and smelting reduction. The process includes two processes-iron oxide reduction and iron particle growth. The product of coal-based reduction is an iron particle, which is different from direct reduction product (DRI) and melts reduction product (liquid molten iron). Phosphorus is a harmful element in most kinds of steel, with the development and exploration of coal-based reduction technology, some research institutes try to treat phosphorus in oolitic hematite by coal-based reduction technology. The main research ideas are the dephosphorization process and phosphorus-rich process. At present, the research on phosphorus in the coal-based reduction process is focused on process optimization, while research on the mechanism of phosphorus reaction behavior and existing form of phosphorus in the metal and slag phase during the coal-based reduction process is still scarce.

The purpose of this study was to investigate the reduction behavior of phosphorus minerals and the existing form of phosphorus in the metal and slag phase during the coal-based reduction of high phosphorus oolitic hematite. On the basis of systematically studying the technological mineralogy of high phosphorus oolitic hematite, the reaction behavior of phosphorus minerals, the effects of various substances on the reduction of phosphorus minerals, and existing form of phosphorus minerals in the metal and slag phase in the coal-based reduction process were investigated by HSC software simulation, thermodynamic calculation, XRD, and SEM-EDS analyses, which could provide theoretical guidance for the ultimate realization of the direct control of phosphorus in the coal-based reduction process.

\section{Materials and Methods}

\subsection{Materials}

The raw material used in the experiment is produced from Guanzhuang, Hubei Province, China. The analysis results of the chemical composition of the ore by potassium dichromate titration and X-ray fluorescence (PW3040 produced by panalytical B. V in the Netherlands) methods are shown in Table 1 . Table 1 shows that the main valent metal element in the ore was iron, the content of total iron was $42.21 \%$, the content of $\mathrm{Fe}_{2} \mathrm{O}_{3}$ was $55.51 \%$, the content of $\mathrm{FeO}$ was $4.31 \%$, and the content of phosphorus was as high as $1.31 \%$. In order to find out the phase composition of iron ore in the ore, the phase analysis of the ore was carried out by using both physical and chemical methods, as shown in Figure 1. The results are shown in Table 2.

Table 1. Chemical element analysis of high phosphorus oolitic hematite ore (mass \%).

\begin{tabular}{cccccccccc}
\hline Component & $\mathrm{TFe}$ & $\mathrm{SiO}_{\mathbf{2}}$ & $\mathrm{Al}_{\mathbf{2}} \mathbf{O}_{\mathbf{3}}$ & $\mathbf{C a O}$ & $\mathbf{M g O}$ & $\mathbf{P}$ & $\mathbf{F e O}$ & $\mathbf{F e}_{\mathbf{2}} \mathbf{O}_{\mathbf{3}}$ & $\mathbf{S}$ \\
\hline Content & 42.21 & 21.80 & 5.47 & 4.33 & 0.59 & 1.31 & 4.31 & 55.51 & 0.13 \\
\hline
\end{tabular}




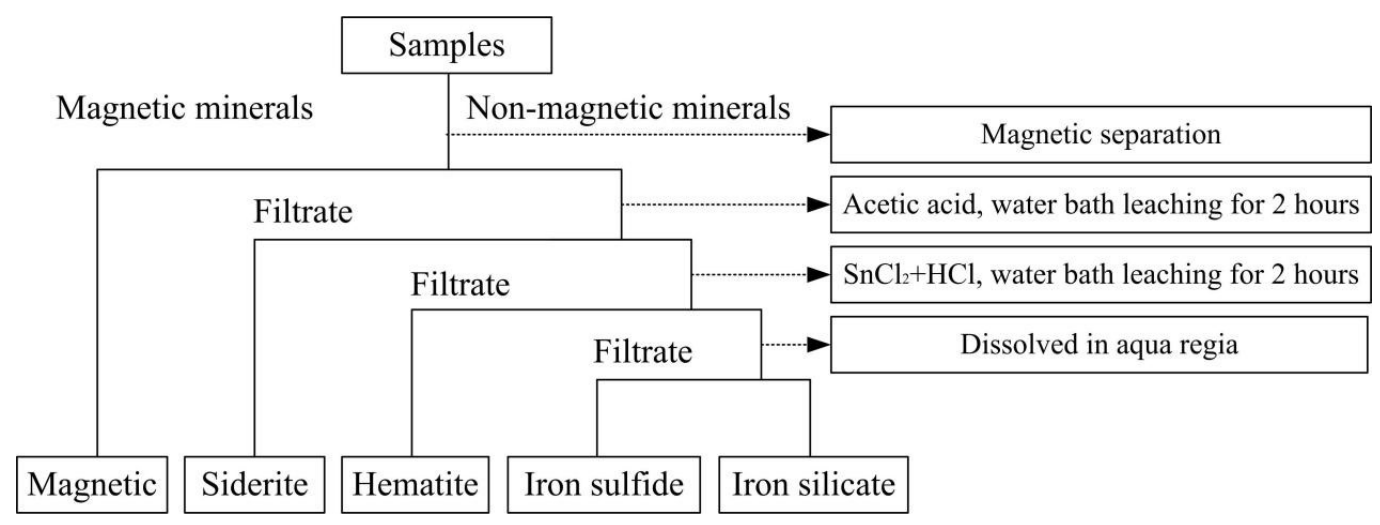

Figure 1. Iron phase analysis process.

Table 2. Analysis result of iron phase (mass \%).

\begin{tabular}{ccccccc}
\hline Phase Analysis of Iron & Iron in Hematite & Iron in Magnetic & Iron in Siderite & Iron in Sulfide & Iron in Silicate & Total \\
\hline Content & 40.97 & 0.54 & 0.37 & 0.13 & 0.19 & 42.21 \\
Distribution rate & 97.09 & 1.28 & 0.88 & 0.31 & 0.45 & 100.00 \\
\hline
\end{tabular}

Table 2 indicates that iron in ores occurred in hematite, magnetite, siderite, sulfide, and silicate minerals. Most irons existed in hematite with a distribution rate of $97.09 \%$. A small amount of iron existed in magnetite and siderite. In order to identify the types of minerals in ore samples further, the qualitative analysis of the mineral phase was carried out by X-ray diffraction analysis. The results are shown in Figure 2. Figure 2 indicates that hematite was the main iron ore, apatite was the main phosphorus mineral, and quartz and oolitic chlorite were the main gangues.

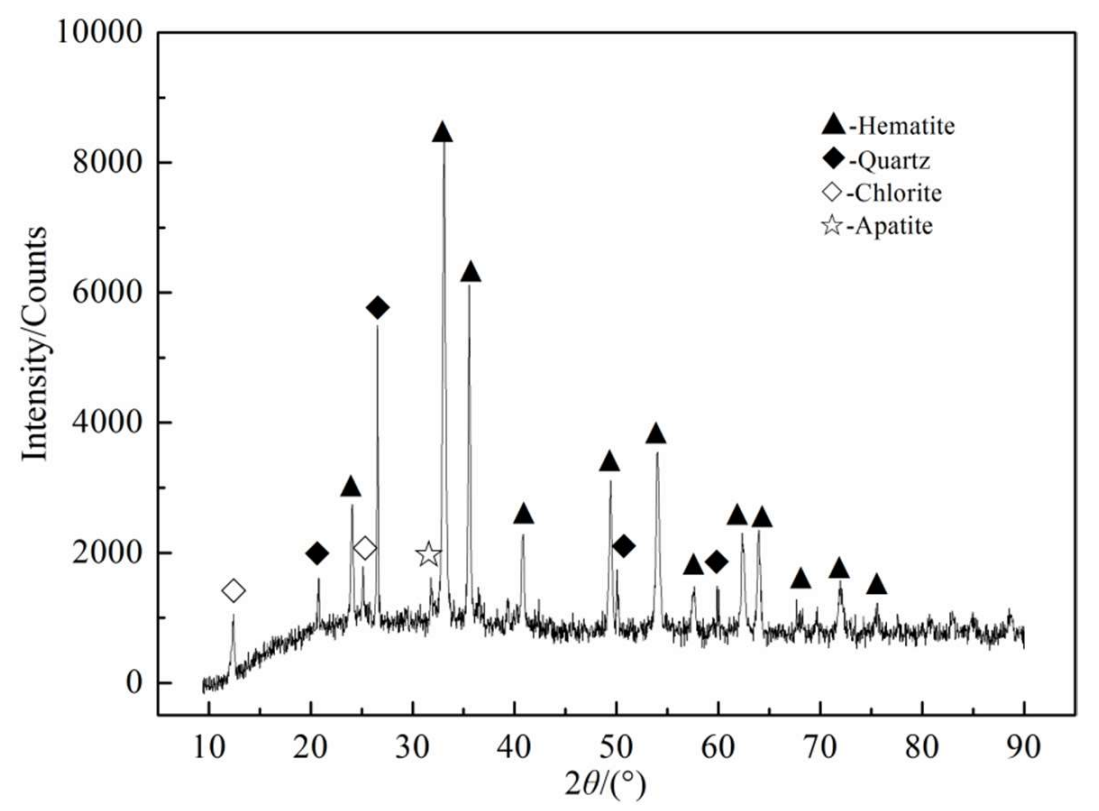

Figure 2. XRD spectrum of raw ore.

In order to simulate the reduction behavior of apatite in high phosphorus oolitic hematite in coal-based reduction, the apatite from Hubei Province was taken as the research object. In order to determine the chemical composition of the apatite and the purity of the apatite, the chemical analysis of the ore was carried out. The results are presented in Table 3. 
Table 3. Chemical composition of apatite ore (mass \%).

\begin{tabular}{cccccccc}
\hline $\mathbf{P}$ & $\mathbf{T F e}$ & $\mathbf{S i O}_{2}$ & $\mathbf{C a O}$ & $\mathbf{A l}_{\mathbf{2}} \mathbf{O}_{3}$ & $\mathbf{M g O}$ & $\mathbf{F}$ & $\mathbf{C l}$ \\
\hline 17.56 & 0.012 & 3.44 & 53.49 & $<0.01$ & $<0.01$ & 4.73 & 0.086 \\
\hline
\end{tabular}

Table 3 states clearly that the content of $\mathrm{CaO}, \mathrm{SiO}_{2}$, and phosphorus was $53.49 \%, 3.44 \%$, and $17.56 \%$, respectively. It can be calculated that the content of $\mathrm{P}_{2} \mathrm{O}_{5}$ in the ore reached $40.22 \%$, indicating that the content of apatite in the apatite ore was very high, which met the requirements of the test (the content of $\mathrm{Ca}_{3}\left(\mathrm{PO}_{4}\right)_{2}$ was $\left.87.80 \%\right)$. Meanwhile, the content of $\mathrm{F}$ was much higher than that of $\mathrm{Cl}$, indicating that the apatite ore was mainly fluoroapatite, which was similar to the main component of apatite in high phosphorous oolitic hematite. In addition, the $\mathrm{SiO}_{2}, \mathrm{Fe}_{2} \mathrm{O}_{3}$, and $\mathrm{Al}_{2} \mathrm{O}_{3}$ used in this experiment were all analytical pure.

\subsection{Methods and Equipment}

The main equipment of coal-based reduction used in this study was a self-made hightemperature box-type resistance furnace (KSL-1400X). The profile of the resistance furnace is shown in Figure 3. Because the reduction furnace was a non-closed system, in order to maintain the reduction atmosphere in the furnace chamber during the coal-based reduction process, the high-temperature box resistance furnace was used to add pulverized coal protection in the crucible. In this study, coal-based reduction technology was used to treat the iron ore. The specific operations were as follows: Firstly, the required amount of high phosphorus oolitic hematite was weighed, and the appropriate amount of pulverized coal through theoretical calculation was added to the dry mixture, and then it was loaded into a crucible. When the temperature in the furnace chamber reached the preset temperature, the crucible was put into the furnace chamber and the temperature was raised to the preset temperature. When the predetermined temperature was reached, the time was started and the temperature was kept constant. After the prescribed time, the reduction products were quickly taken out for water quenching treatment, then they were placed in the oven for drying after the products are cooled. The reduced products were ground to $-0.074 \mathrm{~mm}$ and then subdivided and sampled for further analysis. The schematic diagram of the reduction behavior of apatite and the existing form of phosphorus in coal-based reduction is shown in Figure 3.

In this study, a X-ray diffractometer was used in this experiment. Its working parameters were radiation from the copper target, nickel filter, solid detector, tube voltage $40 \mathrm{kV}$, tube current $40 \mathrm{~mA}$, scanning range 2 Theta $=5-90^{\circ}$, step-by-step scanning, step length $0.033^{\circ}$, residence time $20.68 \mathrm{~s}$ per step, a wavelength of incident line $1.541 \AA$, scanning speed $12^{\circ} \cdot \mathrm{min}^{-1}$, and working temperature $25^{\circ} \mathrm{C}$ [23-26]. In this study, SEM was used to observe the micro-morphology of the reduction products, and EDS could be used to analyze the composition of various elements in the required position of ore after coal-based reduction. The SSX-550 (Shimadzu, Kyoto, Japan) scanning electron microscope produced by Shimadzu Company of Japan was used in this experiment. The working parameters were as follows: acceleration voltage was $15 \mathrm{kV}$, magnification was different. HSC Chemistry 6.0 software (R\&D center of Outokumpu, Finland) was used to calculate and simulate the composition of the equilibrium phase under coal-based reduction [27]. The equilibrium phase components that may exist after reaction equilibrium under different coal-based reduction conditions were obtained. The possibility of the reaction was further calibrated by Gibbs free energy, then the phase analysis of the test materials was carried out by XRD, and the reaction behavior between phosphorus minerals and other minerals in different systems was determined. The effect of other minerals on the reduction of phosphorus minerals was clarified, and the existing form of phosphorus minerals in metal and slag phases was determined. For the sake of simple calculation, it was considered that the chemical formula of apatite in raw ore was $\mathrm{Ca}_{3}\left(\mathrm{PO}_{4}\right)_{2}$. 


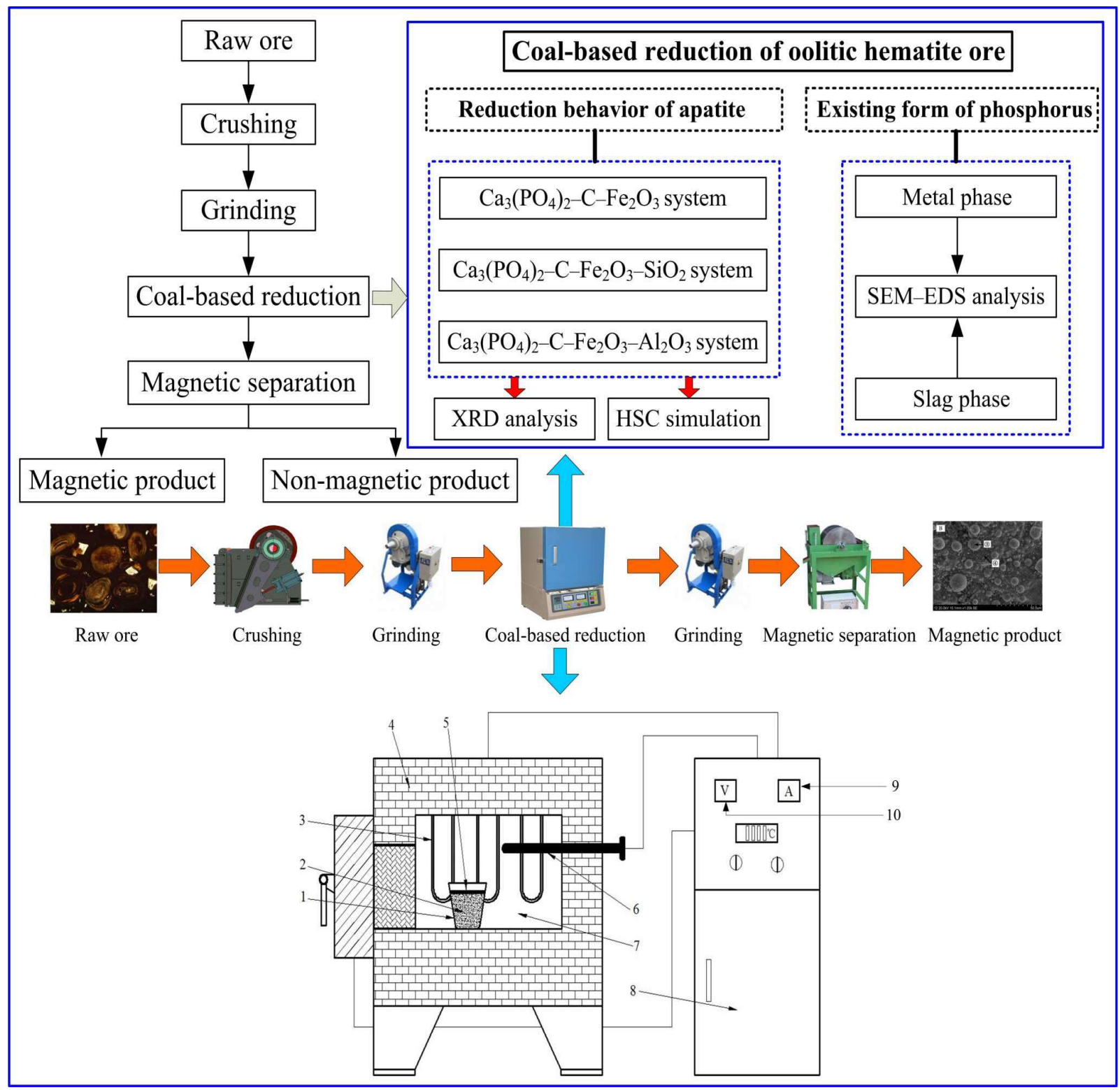

Figure 3. The schematic diagram of reduction behavior of apatite and existing form of phosphorus in coal-based reduction: 1-crucible; 2-reduction product; 3-heating rod; 4-furnace body; 5-protective coal; 6-thermocouple; 7-furnace; 8-control cabinet; 9-ammeter; 10-voltmeter.

\section{Results and Discussion}

\subsection{Analysis of Volatile Phase of Phosphorus}

Phosphorus can be volatilized in the following four forms: $\mathrm{P}_{2}, \mathrm{P}_{4}, \mathrm{PO}$, and $\mathrm{PO}_{2}$. Because of the high content of aluminosilicate gangue minerals in high-phosphorus oolitic hematite, thermodynamic calculations were carried out in the presence of reduction atmosphere of aluminosilicate gangue minerals to determine the form of phosphorus volatilization, as shown in Equations (1)-(4). Equations (1)-(4) show that the relationship between Gtheta and temperature (assuming that the partial pressure of phosphorus gas phase is 0.1) are presented in Figure 4. Figure 4 exhibits that the volatile phases of phosphorus were mainly $\mathrm{P}_{2}$ and $\mathrm{P}_{4}$ gases in the temperature range $\left(1150-1275^{\circ} \mathrm{C}\right)$ of coal-based reduction. 


$$
\begin{aligned}
& \mathrm{Ca}_{3}\left(\mathrm{PO}_{4}\right)_{2}+5 \mathrm{C}+6 \mathrm{SiO}_{2}+3 \mathrm{Al}_{2} \mathrm{O}_{3} \rightarrow 3 \mathrm{CaO} \cdot \mathrm{Al}_{2} \mathrm{O}_{3} \cdot 2 \mathrm{SiO}_{2}+\mathrm{P}(\mathrm{g})+5 \mathrm{CO}(\mathrm{g}) \Delta_{r} G_{m}^{\theta}=1175719-1093 \mathrm{~T} \mathrm{~J} / \mathrm{mol} \\
& 2 \mathrm{Ca}_{3}\left(\mathrm{PO}_{4}\right)_{2}+10 \mathrm{C}+12 \mathrm{SiO}_{2}+6 \mathrm{Al}_{2} \mathrm{O}_{3} \rightarrow 6 \mathrm{CaO} \cdot \mathrm{Al}_{2} \mathrm{O}_{3} \cdot 2 \mathrm{SiO}_{2}+\mathrm{P} \text { (g) }+10 \mathrm{CO}(\mathrm{g}) \Delta_{r} G_{m}^{\theta}=2168820-2039 \mathrm{~T} \mathrm{~J} / \mathrm{mol} \\
& \mathrm{Ca}_{3}\left(\mathrm{PO}_{4}\right)_{2}+3 \mathrm{C}+6 \mathrm{SiO}_{2}+3 \mathrm{Al}_{2} \mathrm{O}_{3} \rightarrow 3 \mathrm{CaO} \cdot \mathrm{Al}_{2} \mathrm{O}_{3} \cdot 2 \mathrm{SiO}_{2}+2 \mathrm{PO}(\mathrm{g})+3 \mathrm{CO}(\mathrm{g}) \Delta_{r} G_{m}^{\theta}=1253228-942 \mathrm{~T} \mathrm{~J} / \mathrm{mol} \\
& \mathrm{Ca}_{3}\left(\mathrm{PO}_{4}\right)_{2}+\mathrm{C}+6 \mathrm{SiO}_{2}+3 \mathrm{Al}_{2} \mathrm{O}_{3} \rightarrow 3 \mathrm{CaO} \cdot \mathrm{Al}_{2} \mathrm{O}_{3} \cdot 2 \mathrm{SiO}_{2}+2 \mathrm{PO}_{2}(\mathrm{~g})+\mathrm{CO}(\mathrm{g}) \Delta_{r} G_{m}^{\theta}=1049089-618 \mathrm{~T} \mathrm{~J} / \mathrm{mol}
\end{aligned}
$$

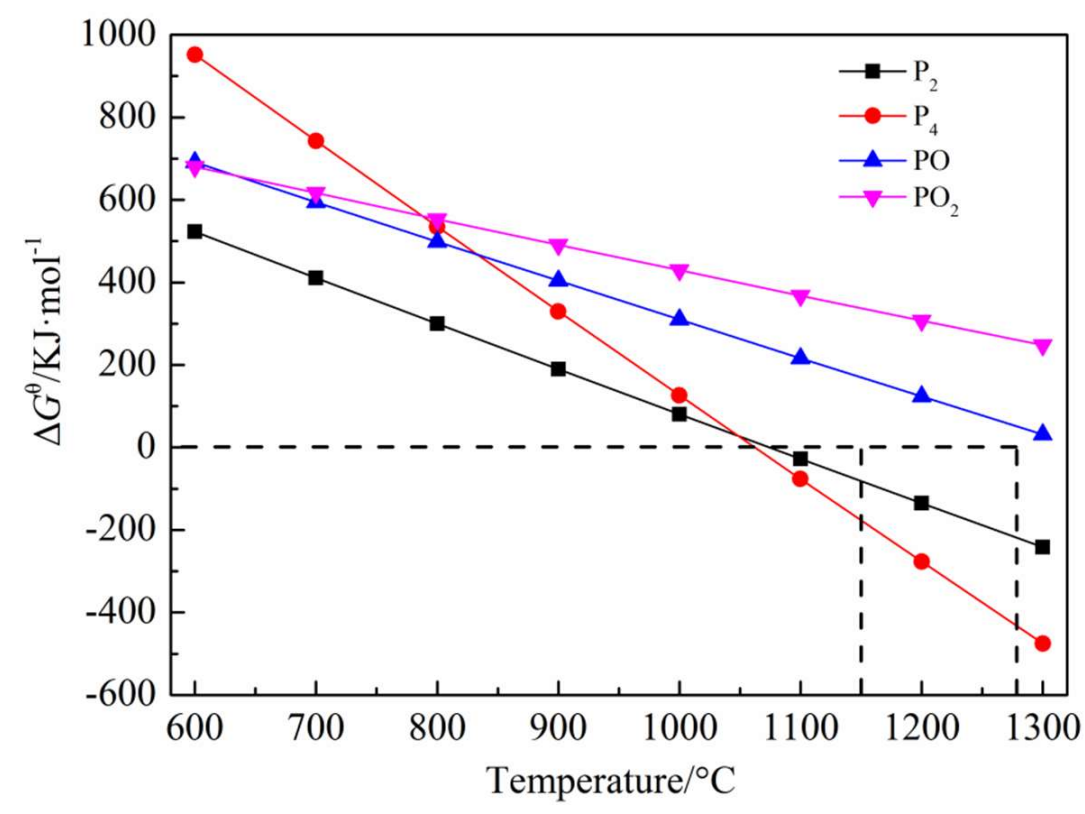

Figure 4. The correlation of $\Delta G^{\theta}$ with temperature for Equations (1)-(4).

\subsection{Reduction Behavior of Phosphorus Minerals}

Based on the idea from easy to difficult and from simple to complex, the reduction behavior of apatite in three systems of $\mathrm{Ca}_{3}\left(\mathrm{PO}_{4}\right)_{2}-\mathrm{C}-\mathrm{Fe}_{2} \mathrm{O}_{3}, \mathrm{Ca}_{3}\left(\mathrm{PO}_{4}\right)_{2}-\mathrm{C}-\mathrm{Fe}_{2} \mathrm{O}_{3}-\mathrm{SiO}_{2}$, and $\mathrm{Ca}_{3}\left(\mathrm{PO}_{4}\right)_{2}-\mathrm{C}-\mathrm{Fe}_{2} \mathrm{O}_{3}-\mathrm{Al}_{2} \mathrm{O}_{3}$ were studied in order to ascertain the effect of each component on the reduction of apatite. The content of $\mathrm{MgO}$ and $\mathrm{CaO}$ in raw ore was relatively low and had little influence on the reaction of apatite. Therefore, the experiments of $\mathrm{MgO}$ and $\mathrm{CaO}$ were not involved in this study.

\subsection{1. $\mathrm{Ca}_{3}\left(\mathrm{PO}_{4}\right)_{2}-\mathrm{C}-\mathrm{Fe}_{2} \mathrm{O}_{3}$ System}

The HSC simulation results of the $\mathrm{Ca}_{3}\left(\mathrm{PO}_{4}\right)_{2}-\mathrm{C}-\mathrm{Fe}_{2} \mathrm{O}_{3}$ system are given in Figure 5 . Figure 5 shows the addition of $\mathrm{Fe}_{2} \mathrm{O}_{3}$ also promoted the reduction of $\mathrm{Ca}_{3}\left(\mathrm{PO}_{4}\right)_{2}$, resulting in the formation of $\mathrm{Fe}$ and $\mathrm{P}$ compounds and $\mathrm{FeO}$. Within the temperature range of coal-based reduction, it was most likely to observe that the solid material was Fe, followed by the compounds of $\mathrm{Fe}, \mathrm{P}$, and $\mathrm{FeO}$. Among them, the compounds of iron and phosphorus may be $\mathrm{FeP}, \mathrm{Fe}_{2} \mathrm{P}$, and $\mathrm{Fe}_{3} \mathrm{P}$. The specific equation is shown in Equations (5)-(7). Equations (5)-(7) indicate that all three compounds formed by the combination of iron and phosphorus can be produced in the temperature range of coal-based reduction. The actual reduction test results of $\mathrm{Ca}_{3}\left(\mathrm{PO}_{4}\right)_{2}-\mathrm{C}-\mathrm{Fe}_{2} \mathrm{O}_{3}$ are shown in Figure 6. Figure 6 shows that the presence of metal iron and fusiform $\mathrm{FeO}$ was observed in the XRD spectra of reducing materials, but no iron and phosphorus compounds were observed, which indicated that apatite had not been reduced and only iron was reduced in $\mathrm{Ca}_{3}\left(\mathrm{PO}_{4}\right)_{2}-\mathrm{C}-\mathrm{Fe}_{2} \mathrm{O}_{3}$ system. 


$$
\begin{gathered}
\mathrm{Ca}_{3}\left(\mathrm{PO}_{4}\right)_{2}+9.5 \mathrm{C}+1.5 \mathrm{Fe}_{2} \mathrm{O}_{3} \rightarrow 9.5 \mathrm{CO}(\mathrm{g})+2 \mathrm{FeP}+3 \mathrm{CaO}+\mathrm{Fe} \Delta_{r} G_{m}^{\theta}=1705484-1631 \mathrm{~T} \mathrm{~J} \cdot \mathrm{mol}^{-1} \\
\text { Assuming } \Delta_{r} G_{m}^{\theta}=0 \text {, then } \mathrm{T}=1046{ }^{\circ} \mathrm{C} \\
\mathrm{Ca}_{3}\left(\mathrm{PO}_{4}\right)_{2}+12.5 \mathrm{C}+2.5 \mathrm{Fe}_{2} \mathrm{O}_{3} \rightarrow 12.5 \mathrm{CO}(\mathrm{g})+2 \mathrm{Fe}_{2} \mathrm{P}+3 \mathrm{CaO}+\mathrm{Fe} \Delta_{r} G_{m}^{\theta}=1947237-2105 \mathrm{~T} \mathrm{~J} \cdot \mathrm{mol}^{-1} \\
\text { Assuming } \Delta_{r} G_{m}^{\theta}=0 \text {, then T }=925{ }^{\circ} \mathrm{C} \\
\mathrm{Ca}_{3}\left(\mathrm{PO}_{4}\right)_{2}+15.5 \mathrm{C}+3.5 \mathrm{Fe}_{2} \mathrm{O}_{3} \rightarrow 15.5 \mathrm{CO}(\mathrm{g})+2 \mathrm{Fe}_{3} \mathrm{P}+3 \mathrm{CaO}+\mathrm{Fe} \Delta_{r} G_{m}^{\theta}=2245844-2615 \mathrm{~T} \mathrm{~J} \cdot \mathrm{mol}^{-1} \\
\text { Assuming } \Delta_{r} G_{m}^{\theta}=0 \text {, then } \mathrm{T}=859{ }^{\circ} \mathrm{C}
\end{gathered}
$$

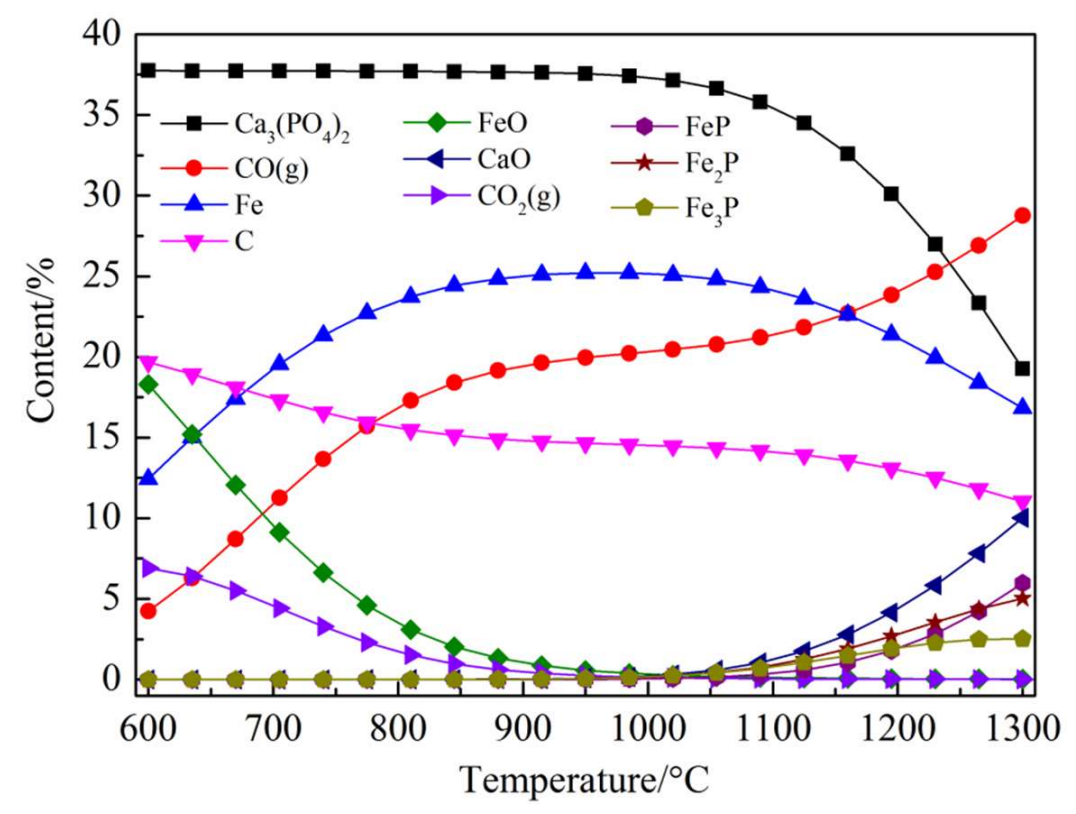

Figure 5. Thermodynamic equilibrium composition in the $\mathrm{Ca}_{3}\left(\mathrm{PO}_{4}\right)_{2}-\mathrm{C}-\mathrm{Fe}_{2} \mathrm{O}_{3}$ system.

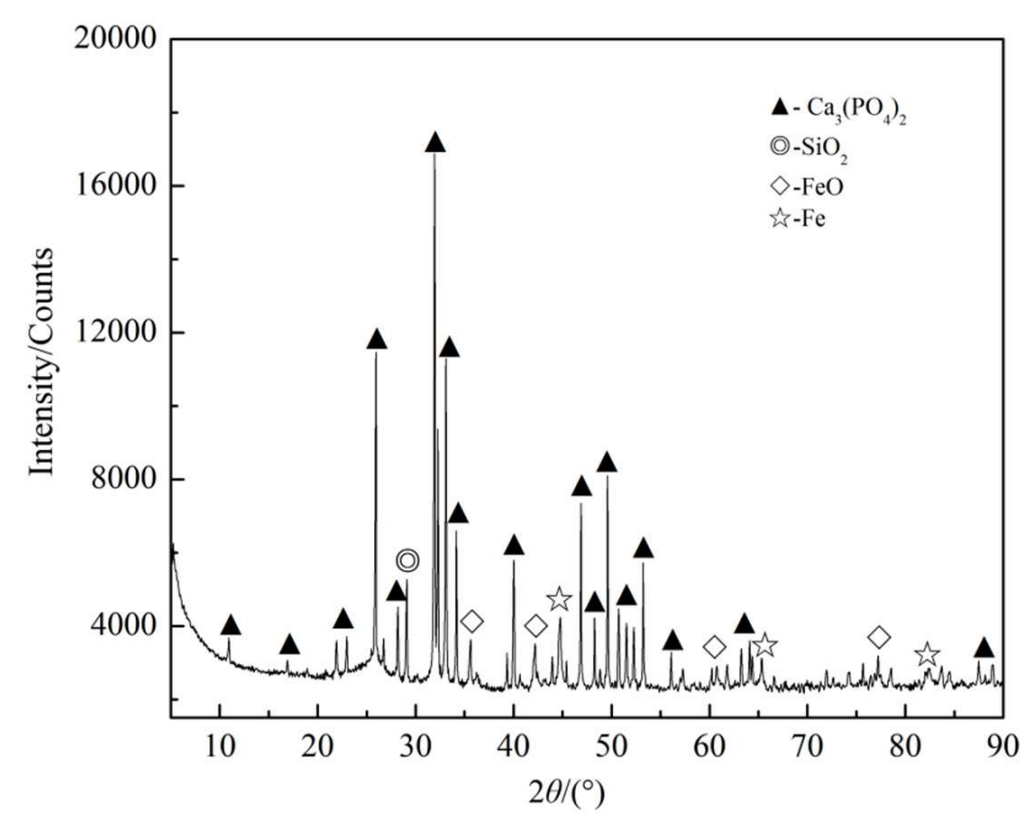

Figure 6. XRD analysis of the $\mathrm{Ca}_{3}\left(\mathrm{PO}_{4}\right)_{2}-\mathrm{C}-\mathrm{Fe}_{2} \mathrm{O}_{3}$ system after coal-based reduction.

\subsection{2. $\mathrm{Ca}_{3}\left(\mathrm{PO}_{4}\right)_{2}-\mathrm{C}-\mathrm{Fe}_{2} \mathrm{O}_{3}-\mathrm{SiO}_{2}$ System}

The HSC simulation results of the $\mathrm{Ca}_{3}\left(\mathrm{PO}_{4}\right)_{2}-\mathrm{C}-\mathrm{Fe}_{2} \mathrm{O}_{3}-\mathrm{SiO}_{2}$ system are shown in Figure 7. Figure 7 indicates that in the $\mathrm{Ca}_{3}\left(\mathrm{PO}_{4}\right)_{2}-\mathrm{C}-\mathrm{Fe}_{2} \mathrm{O}_{3}-\mathrm{SiO}_{2}$ system, apatite had been thoroughly reduced. $\mathrm{FeP}$ and $\mathrm{Fe}_{2} \mathrm{P}$ were formed when apatite was reduced and combined 
with iron. $\mathrm{Fe}_{2} \mathrm{O}_{3}$ was reduced to form metal iron, and a small amount of iron olivine might exist. Other solid substances that might be observed should be $\mathrm{CaSiO}_{3}$ and $2 \mathrm{CaO} \cdot \mathrm{SiO}_{2}$. The actual reduction test results of the $\mathrm{Ca}_{3}\left(\mathrm{PO}_{4}\right)_{2}-\mathrm{C}-\mathrm{Fe}_{2} \mathrm{O}_{3}-\mathrm{SiO}_{2}$ system are presented in Figure 8. Figure 8 states clearly that in the XRD spectra of reducing materials, except for some unreacted quartz and apatite, the presence of iron, iron olivine, and $\mathrm{CaSiO}_{3}$ was observed, and the presence of iron and phosphorus compounds FeP was also observed, which was in good agreement with the HSC simulation results.

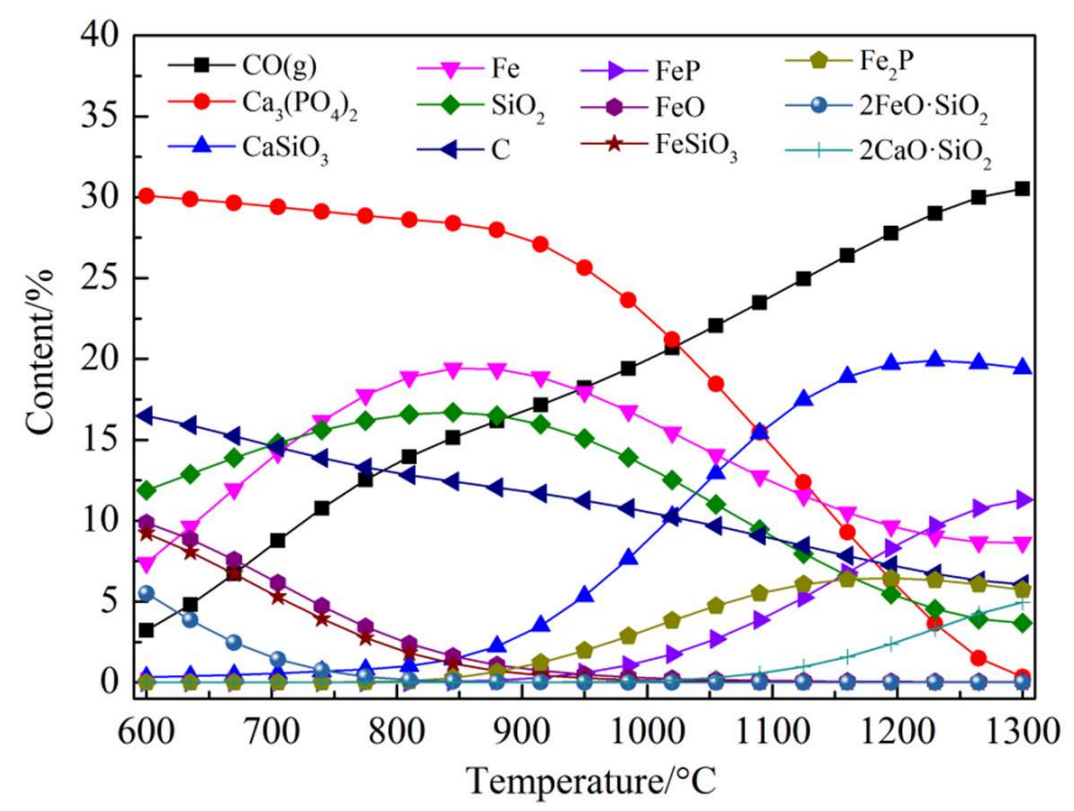

Figure 7. Thermodynamic equilibrium composition in the $\mathrm{Ca}_{3}\left(\mathrm{PO}_{4}\right)_{2}-\mathrm{C}-\mathrm{Fe}_{2} \mathrm{O}_{3}-\mathrm{SiO}_{2}$ system.

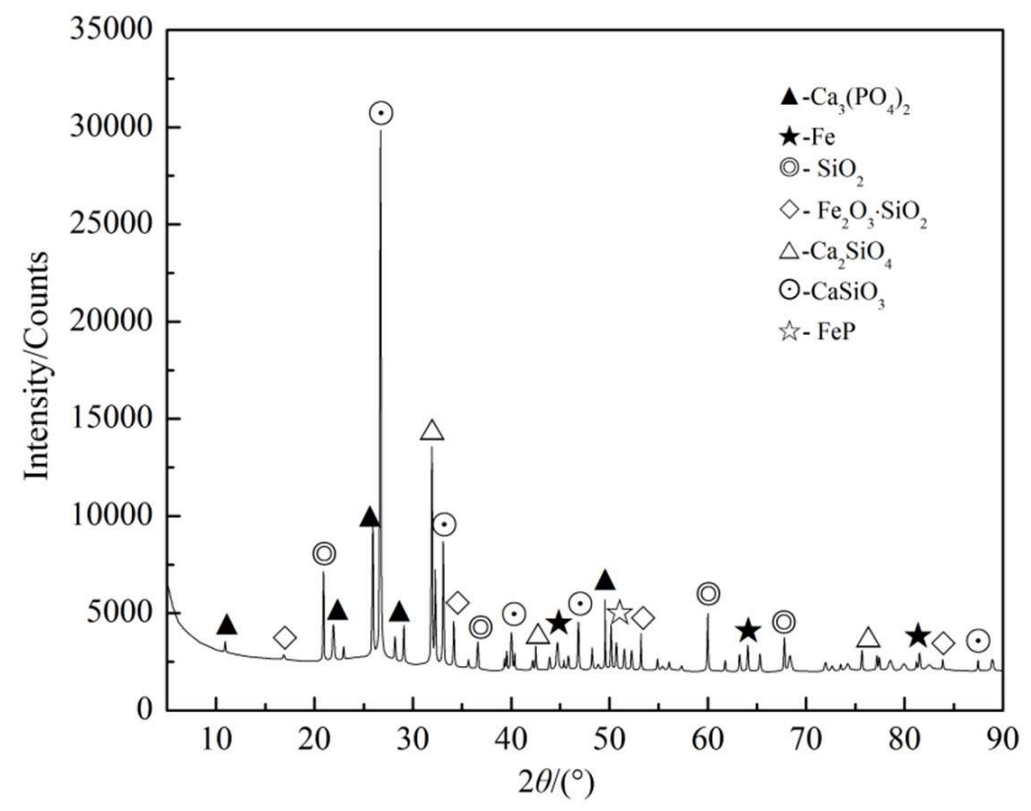

Figure 8. XRD analysis of the $\mathrm{Ca}_{3}\left(\mathrm{PO}_{4}\right)_{2}-\mathrm{C}-\mathrm{Fe}_{2} \mathrm{O}_{3}-\mathrm{SiO}_{2}$ system after coal-based reduction.

\subsection{3. $\mathrm{Ca}_{3}\left(\mathrm{PO}_{4}\right)_{2}-\mathrm{C}-\mathrm{Fe}_{2} \mathrm{O}_{3}-\mathrm{Al}_{2} \mathrm{O}_{3}$ System}

The HSC simulation results of the $\mathrm{Ca}_{3}\left(\mathrm{PO}_{4}\right)_{2}-\mathrm{C}-\mathrm{Fe}_{2} \mathrm{O}_{3}-\mathrm{Al}_{2} \mathrm{O}_{3}$ system are shown in Figure 9. Figure 9 shows that in the $\mathrm{Ca}_{3}\left(\mathrm{PO}_{4}\right)_{2}-\mathrm{C}-\mathrm{Fe}_{2} \mathrm{O}_{3}-\mathrm{Al}_{2} \mathrm{O}_{3}$ system, $\mathrm{Fe}_{2} \mathrm{O}_{3}$ was reduced to form metal iron, and apatite was reduced to form $\mathrm{FeP}, \mathrm{Fe}_{2} \mathrm{P}$, and $\mathrm{Fe}_{3} \mathrm{P}$ by combining with iron. There might also be some alumina spinel. Compared with the $\mathrm{Ca}_{3}\left(\mathrm{PO}_{4}\right)_{2}-\mathrm{C}-$ 
$\mathrm{Fe}_{2} \mathrm{O}_{3}-\mathrm{SiO}_{2}$ system, apatite was not completely reduced. Other solid substances that might be observed were $\mathrm{CaO} \cdot \mathrm{Al}_{2} \mathrm{O}_{3}$ and $2 \mathrm{CaO} \cdot \mathrm{Al}_{2} \mathrm{O}_{3}$. The actual reduction test results are presented in Figure 10. Figure 10 exhibits that iron spinel, $\mathrm{CaO} \cdot \mathrm{Al}_{2} \mathrm{O}_{3}$, and $2 \mathrm{CaO} \cdot \mathrm{Al}_{2} \mathrm{O}_{3}$ were observed in the XRD spectra of reducing materials in the $\mathrm{Ca}_{3}\left(\mathrm{PO}_{4}\right)_{2}-\mathrm{C}-\mathrm{Fe}_{2} \mathrm{O}_{3}-\mathrm{Al}_{2} \mathrm{O}_{3}$ system, which was in good agreement with HSC simulation results. It can be seen from the above that the addition of $\mathrm{Al}_{2} \mathrm{O}_{3}$ alone could not reduce apatite, so the presence of iron and phosphorus compounds could not be observed. Therefore, the reduction of the $\mathrm{Ca}_{3}\left(\mathrm{PO}_{4}\right)_{2}-\mathrm{C}-\mathrm{Fe}_{2} \mathrm{O}_{3}-\mathrm{Al}_{2} \mathrm{O}_{3}$ system was mainly the reduction of $\mathrm{Fe}_{2} \mathrm{O}_{3}$.

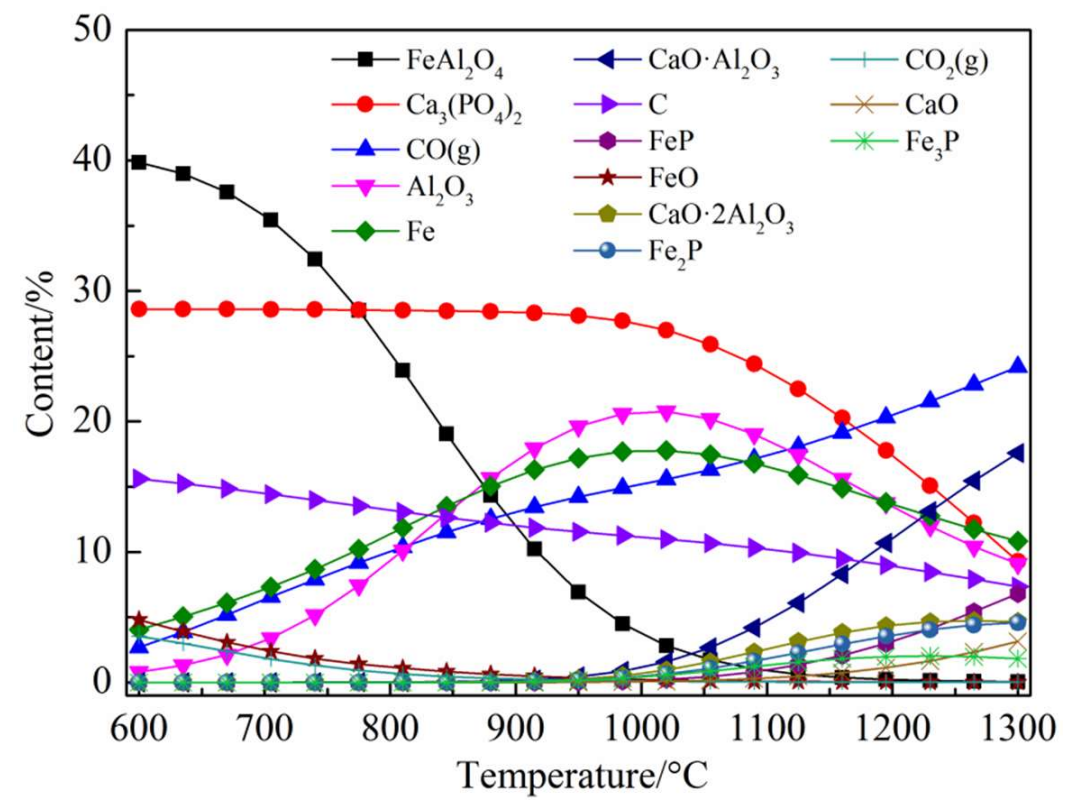

Figure 9. Thermodynamic equilibrium composition in the $\mathrm{Ca}_{3}\left(\mathrm{PO}_{4}\right)_{2}-\mathrm{C}-\mathrm{Fe}_{2} \mathrm{O}_{3}-\mathrm{Al}_{2} \mathrm{O}_{3}$ system.

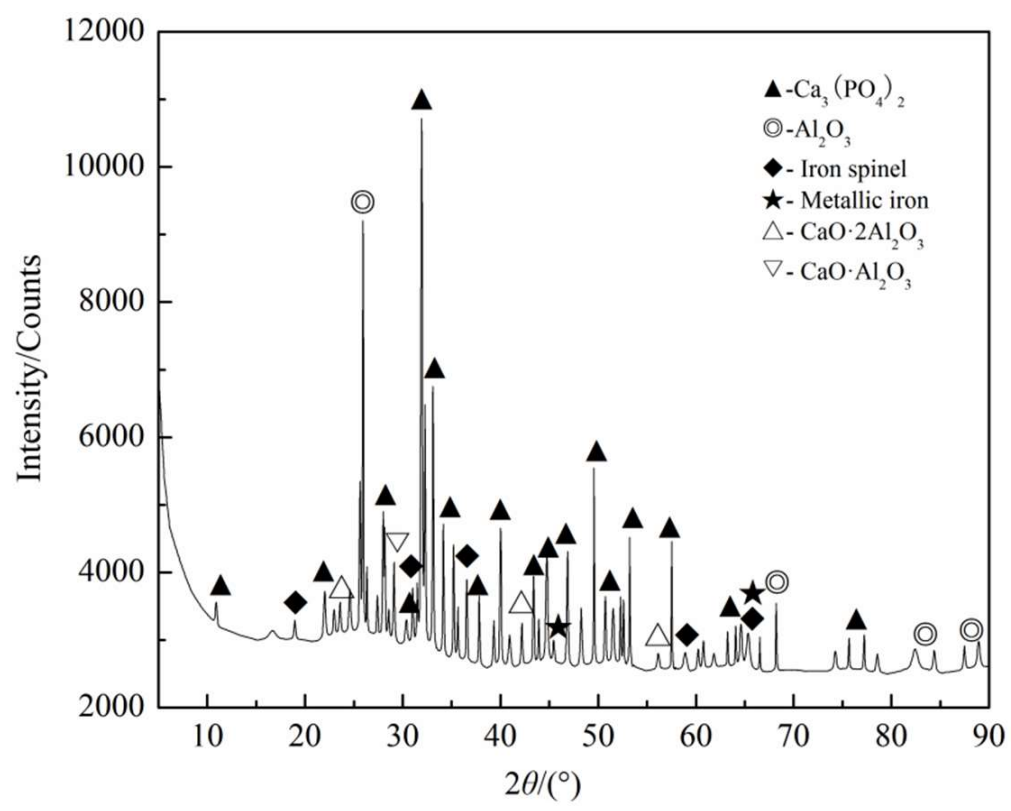

Figure 10. XRD analysis of the $\mathrm{Ca}_{3}\left(\mathrm{PO}_{4}\right)_{2}-\mathrm{C}-\mathrm{Fe}_{2} \mathrm{O}_{3}-\mathrm{Al}_{2} \mathrm{O}_{3}$ system after coal-based reduction.

\subsection{Existing Form of Phosphorus}

3.3.1. Phosphorus in the Metal Phase

In the field of metallurgy, the phase diagram of the $\mathrm{Fe}-\mathrm{P}$ system had been agreed that the alloy could form three kinds of compounds- $-\mathrm{FeP}, \mathrm{Fe}_{2} \mathrm{P}$, and $\mathrm{Fe}_{3} \mathrm{P}$. Based on the atomic 
and molecular coexistence theory of metal melts containing compounds and the previous research results, the above compounds could exist in high-temperature liquid alloys by comparing and calculating different schemes, and the results were in line with the actual situation. The equation involved is shown in Equations (8)-(10). The relationship between Gibbs free energy and temperature in each reaction is given in Figure 11. It can be found from Figure 11 that according to thermodynamic analysis, three compounds $\left(\mathrm{FeP}, \mathrm{Fe}_{2} \mathrm{P}\right.$, and $\mathrm{Fe}_{3} \mathrm{P}$ ) could be easily formed in the coal-based reduction process. In theory, the most easily formed substance should be $\mathrm{Fe}_{3} \mathrm{P}$, followed by $\mathrm{Fe}_{2} \mathrm{P}$, and finally, $\mathrm{FeP}$.

$$
\begin{aligned}
& 2 \mathrm{Fe}+\mathrm{P}_{2}(\mathrm{~g}) \rightarrow 2 \mathrm{FeP} ; \Delta_{r} G_{m}^{\theta}=-2765034+150 \mathrm{~T} \mathrm{~J} \cdot \mathrm{mol}^{-1} \\
& 4 \mathrm{Fe}+\mathrm{P}_{2}(\mathrm{~g}) \rightarrow 2 \mathrm{Fe}_{2} \mathrm{P} ; \Delta_{r} G_{m}^{\theta}=-363460+185 \mathrm{~T} \mathrm{~J} \cdot \mathrm{mol}^{-1} \\
& 6 \mathrm{Fe}+\mathrm{P}_{2}(\mathrm{~g}) \rightarrow 2 \mathrm{Fe}_{3} \mathrm{P} ; \Delta_{r} G_{m}^{\theta}=-393563+185 \mathrm{~T} \mathrm{~J} \cdot \mathrm{mol}^{-1}
\end{aligned}
$$

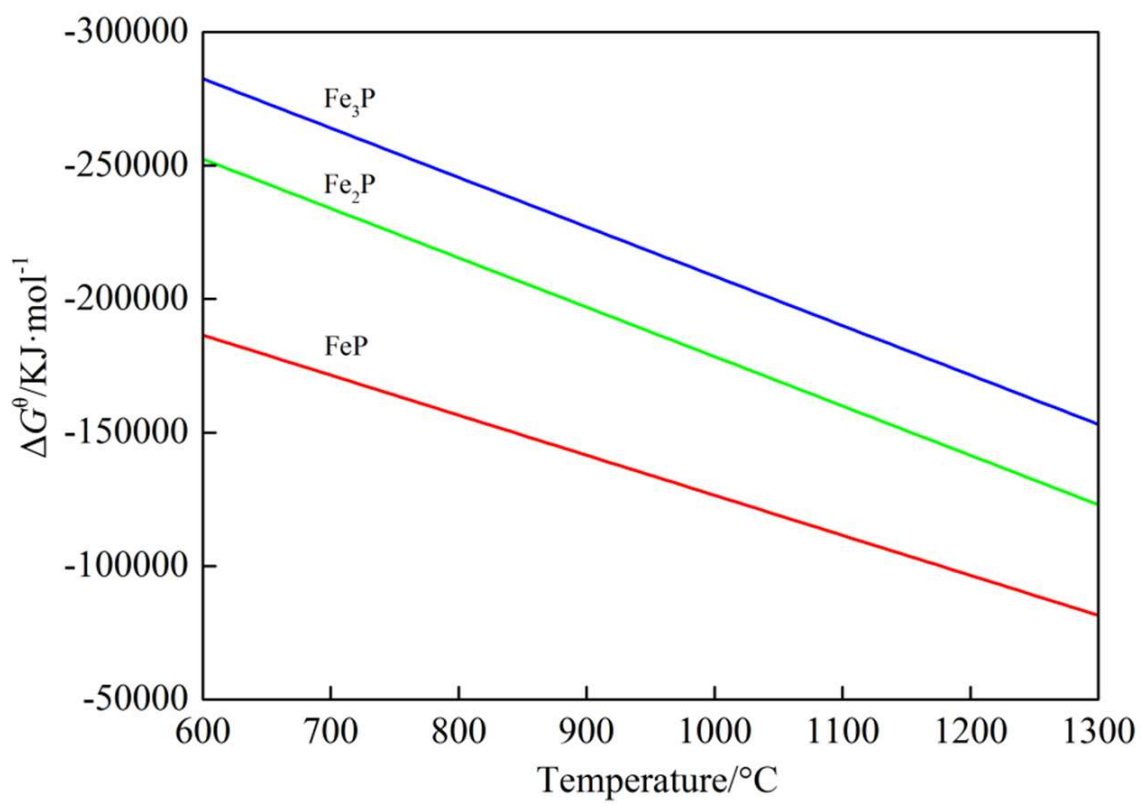

Figure 11. The correlation of $\Delta G^{\theta}$ with temperature for Equations (8)-(10).

In order to determine the existing form of phosphorus in the metal phase after coal-based reduction of high-phosphorus oolitic hematite, coal-based reduction samples were prepared by reducing high-phosphorus oolitic hematite for $60 \mathrm{~min}$ at $1250{ }^{\circ} \mathrm{C}$ and $\mathrm{C} / \mathrm{O}$ molar ratio of 2.0. The metal phase in the sample was observed by scanning electron microscopy, and the surface scanning analysis and spot scanning analysis of Fe and P elements in the metal phase area was carried out. The results are shown in Figures 12 and 13, respectively.

Figure 12 demonstrates clearly that the metal phase was divided into light gray and bright gray. The bright gray area was mainly distributed at the boundary of the metal phase, indicating that the composition of the metal phase was not uniform. From the surface distribution of $\mathrm{Fe}$ and $\mathrm{P}$ elements, it was found that $\mathrm{P}$ elements were mainly concentrated in the bright gray area, while P elements were relatively dispersed in the light gray area. On the contrary, the distribution of Fe elements was in the light gray area. The results show that the content of $\mathrm{P}$ was relatively high at the boundary of the metal phase (bright gray area). In order to further clarify the material composition of light gray and bright gray areas in the metallographic phase, an EDS energy spectrometer (Quantax 200 made by Bruker company in Germany) was used to quantitatively analyze the composition of micro-areas in different areas. The results are shown in Figure 13. EDS results show that the main component of light gray and bright gray areas was $\mathrm{Fe}$, which contained a certain amount of $\mathrm{P}$, but the phosphorus content of the two areas was quite different. The content 
of Fe and $\mathrm{P}$ was $84.21 \%$ and $15.79 \%$ at the position of spot 1 (bright gray area), respectively. The ratio of them was 5.33, which was very close to the mass ratio of $\mathrm{Fe}$ and $\mathrm{P}$ in $\mathrm{Fe}_{3} \mathrm{P}$ (5.42). Therefore, it can be inferred that the material in the bright gray area was $\mathrm{Fe}_{3} \mathrm{P}$. The ratios of Fe and $\mathrm{P}$ at spot 2 and spot 3 (light gray region) were 53.64 and 35.76, respectively, which were much larger than 5.42. Meanwhile, SEM images show that the gray region was homogeneous in texture and there was no obvious iron-phosphorus compound phase, indicating that $\mathrm{P}$ in this region did not form a compound with $\mathrm{Fe}$, and $\mathrm{P}$ should be solute in metal iron.

\subsubsection{Phosphorus in the Slag Phase}

Scholars at home and abroad had carried out many in-depth and systematic studies on the occurrence and migration of phosphorus in steel slag. The results show that the $\mathrm{CaO}-\mathrm{SiO}_{2}$ phase in the slag phase was the enrichment site of phosphorus, and phosphorus mainly existed in $\mathrm{CaO}-\mathrm{SiO}_{2}-\mathrm{P}_{2} \mathrm{O}_{5}$ solid solution in the $\mathrm{CaO}-\mathrm{SiO}_{2}$ phase $[28,29]$. Inoue and Suitoo found that the rate of phosphorus transfer to $2 \mathrm{CaO} \cdot \mathrm{SiO}_{2}$ particles was very fast in the slag phase, and homogeneous $2 \mathrm{CaO} \cdot \mathrm{SiO}_{2}-3 \mathrm{CaO} \cdot \mathrm{P}_{2} \mathrm{O}_{5}$ solid solution phase was formed within five seconds [30,31]. Fukagai et al. [32] studied the formation mechanism of $\mathrm{CaO}-\mathrm{SiO}_{2}-\mathrm{P}_{2} \mathrm{O}_{5}$ solid solution in molten slag at $1573 \mathrm{~K}$. It was found that $\mathrm{P}_{2} \mathrm{O}_{5}$ in the slag phase diffused rapidly to the interface of $2 \mathrm{CaO} \cdot \mathrm{SiO}_{2}$ and formed $\mathrm{CaO}-\mathrm{SiO}_{2}-\mathrm{P}_{2} \mathrm{O}_{5}$ solid solution phase. Yang et al. [33] studied the distribution of $\mathrm{P}_{2} \mathrm{O}_{5}$ near the interface between $2 \mathrm{CaO} \cdot \mathrm{SiO}_{2}$ particles and $\mathrm{CaO} \cdot \mathrm{SiO}_{2}-\mathrm{FeO}_{x}-\mathrm{P}_{2} \mathrm{O}_{5}$ slag system. It was considered that $\mathrm{P}_{2} \mathrm{O}_{5}$ was enriched within a certain range of $2 \mathrm{CaO} \cdot \mathrm{SiO}_{2}$ particles, and the temperature played a positive role in the enrichment of $\mathrm{P}_{2} \mathrm{O}_{5}$.
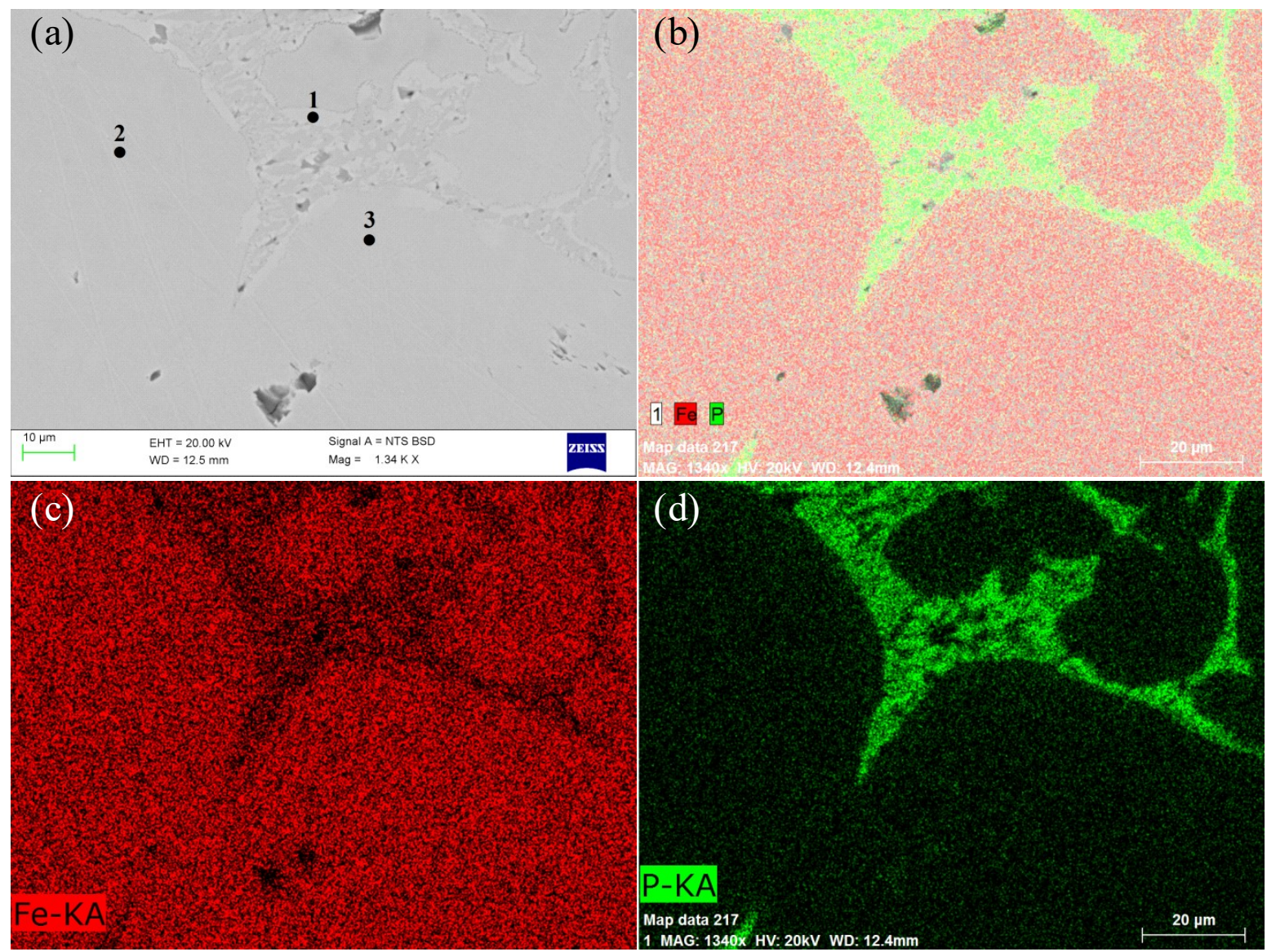

Figure 12. SEM-EDS images of metal phase: (a) SEM image; (b) the surface scanning analysis of Fe and P elements; (c) the surface scanning analysis of Fe elements; and (d) the surface scanning analysis of $P$ elements. 


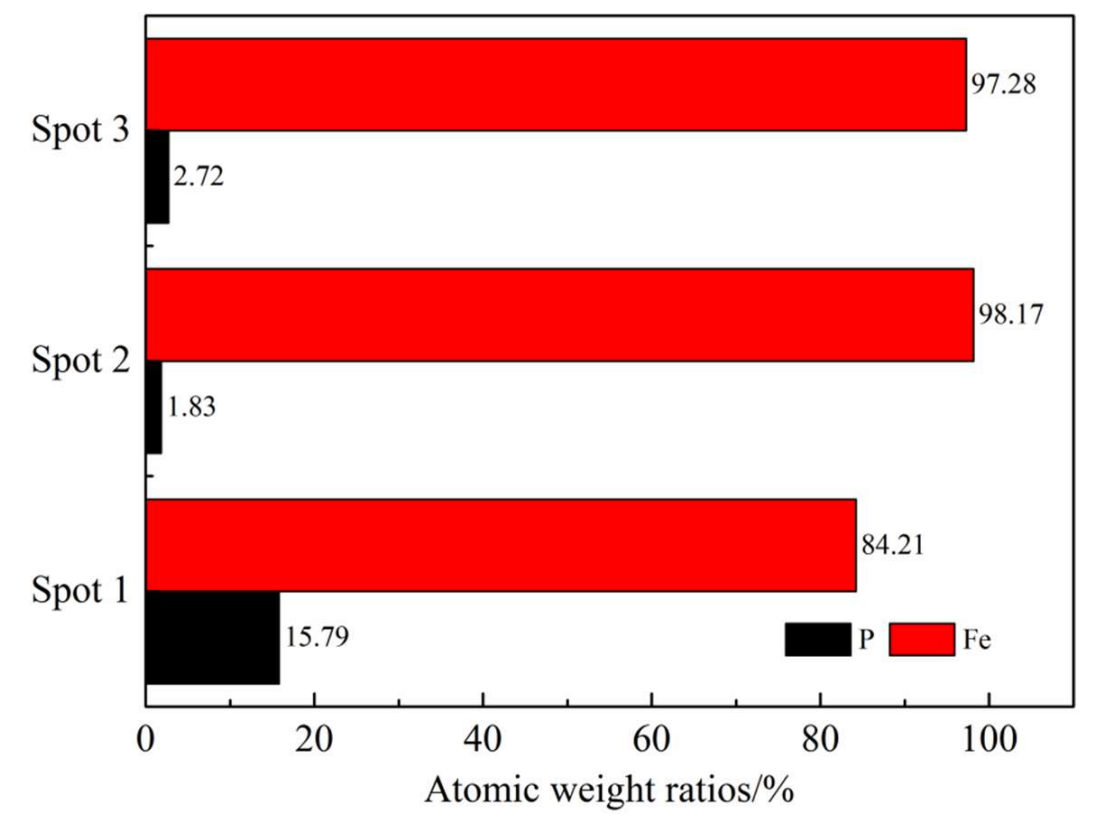

Figure 13. EDS analysis results of spots 1 to 3 in the metal phase.

In the process of coal-based reduction, phosphorus minerals were indeed reduced to elemental phosphorus. In the range of coal-based reduction temperature, elemental phosphorus exists in the form of a gas phase. The gas-phase form of phosphorus was less stable and could be converted into oxides in the limited oxygen environment. Therefore, when phosphorus migrated in the slag phase, it reacted with a very small amount of $\mathrm{CO}_{2}$ in the system to form $\mathrm{P}_{2} \mathrm{O}_{5}$ (sublimation temperature $360^{\circ} \mathrm{C}$ ) gas. The reaction is shown in Equation (11).

$$
\mathrm{P}_{2}(\mathrm{~g})+5 \mathrm{CO}_{2}(\mathrm{~g}) \rightarrow \mathrm{P}_{2} \mathrm{O}_{5}(\mathrm{~g})+5 \mathrm{CO}(\mathrm{g})
$$

The standard Gibbs free energy change of the above reaction was calculated by HSC Chemistry 6.0 thermodynamic calculation software. The results show that when the temperature was higher than $1177^{\circ} \mathrm{C}$, the standard Gibbs free energy change of reaction Equation (11) began to be less than 0, which indicated that reaction Equation (11) could be carried out. The temperature of coal-based reduction of ore was higher than or close to $1177^{\circ} \mathrm{C}$, which showed that $\mathrm{P}_{2} \mathrm{O}_{5}$ was formed when phosphorus was reduced through the slag phase. The $\mathrm{CaO}-\mathrm{SiO}_{2}$ phase was the enrichment site of phosphorus in the slag phase. Therefore, the generated $\mathrm{P}_{2} \mathrm{O}_{5}$ would be captured by $\mathrm{CaO}-\mathrm{SiO}_{2}$ in the slag phase to form $\mathrm{CaO}-\mathrm{SiO}_{2}-\mathrm{P}_{2} \mathrm{O}_{5}$ solid solution.

In order to clarify the existing form of phosphorus in the slag phase of coal-based reduction material of high phosphorus oolitic hematite, the slag phase of reduction sample (reduction temperature $1250{ }^{\circ} \mathrm{C}$, reduction time $60 \mathrm{~min}, \mathrm{C} / \mathrm{O}$ molar ratio 2.0) was also analyzed by SEM. The results are shown in Figure 14.

Figure 14 indicates that the slag phase was obviously divided into three areas-gray, dark gray, and light gray. Meanwhile, it can be found that the three areas in the slag phase were homogeneous in texture, indicating that the slag phase was mainly composed of three substances. From the surface distribution of $\mathrm{P}, \mathrm{Si}, \mathrm{O}$, and $\mathrm{Ca}$ elements, it is evident that the distribution of $\mathrm{O}$ elements was relatively uniform in the whole scanning area, $\mathrm{P}$ elements were mainly concentrated in the gray area, Ca elements were concentrated in the gray area and the dark gray area, Si elements were obviously distributed in the whole scanning area, and the distribution of Si elements was the most concentrated in the light gray area, followed by the gray area. Element surface scanning results show that the gray area was the enrichment site of phosphorus in the slag phase. 

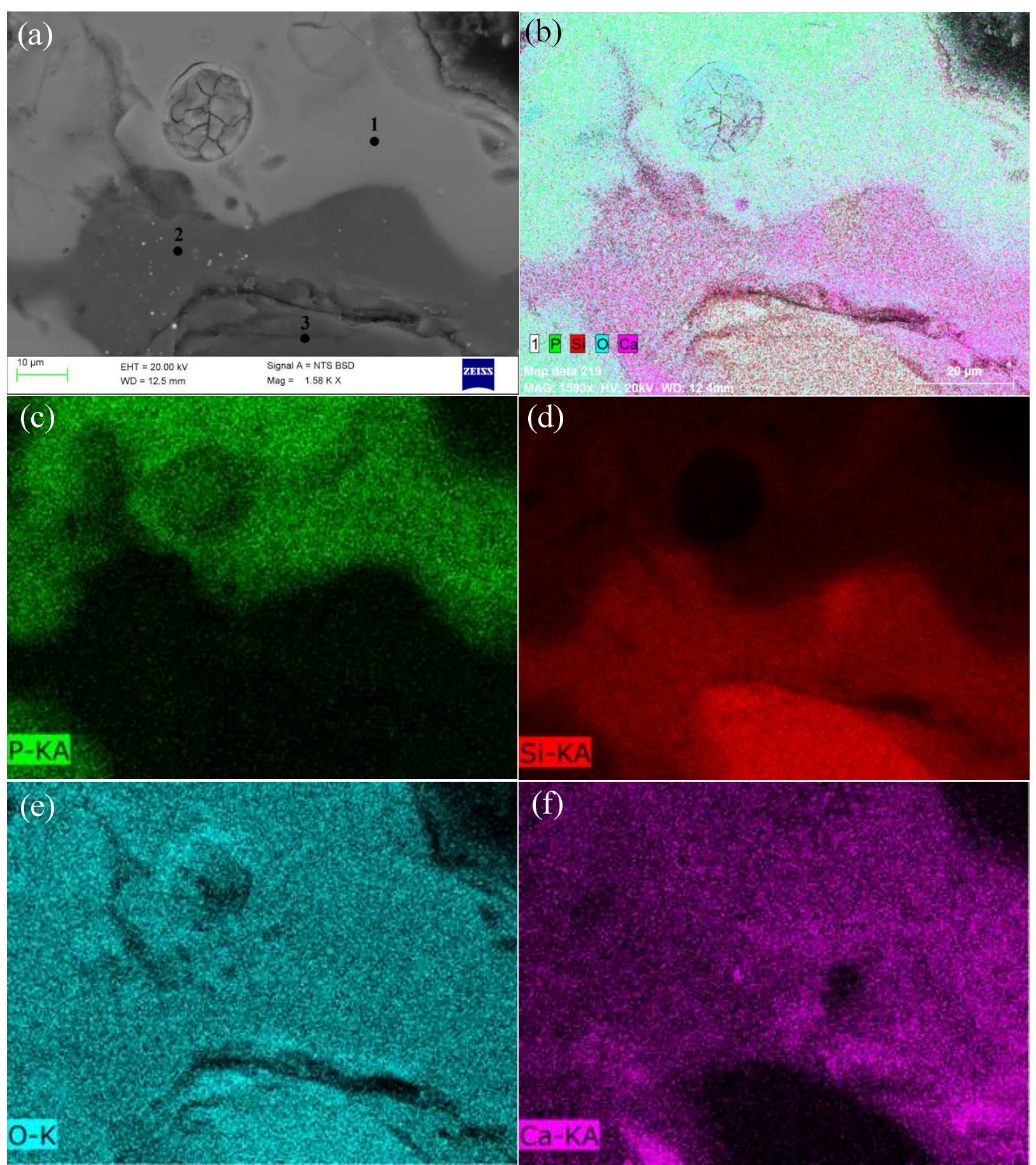

Figure 14. SEM-EDS images of slag phase: (a) SEM image; (b) the surface scanning analysis of $\mathrm{P}, \mathrm{Si}, \mathrm{O}$, and Ca elements; (c) the surface scanning analysis of P elements; (d) the surface scanning analysis of Si elements; (e) the surface scanning analysis of $\mathrm{O}$ elements; and (f) the surface scanning analysis of Ca elements.

The surface scanning analysis of $\mathrm{Si}, \mathrm{O}$, and $\mathrm{Ca}$ was not enough to judge the material composition of each region. Therefore, the EDS energy spectrum was used to quantitatively analyze the micro-component of the slag phase. The results are shown in Figure 15. Quantitative analysis by EDS shows that the gray area (spot 1 ) consisted of $\mathrm{P}, \mathrm{Si}, \mathrm{Ca}, \mathrm{Al}$, and $\mathrm{O}$ elements with contents of $14.27 \%, 16.84 \%, 12.53 \%, 54.67 \%$, and $1.69 \%$, respectively; the dark gray area (spot 2) consisted of $\mathrm{Si}, \mathrm{Ca}, \mathrm{Al}$, and $\mathrm{O}$ elements with contents of $35.99 \%$, $4.56 \%, 11.36 \%$, and $48.09 \%$, respectively; the light gray area (spot 3 ) consisted of $\mathrm{Si}$ and O elements with contents of $49.63 \%$ and $50.37 \%$, respectively. When the element content 
in the above area was converted into oxide content, the material composition in the gray area was mainly $17.54 \% \mathrm{CaO}-36.09 \% \mathrm{SiO}_{2}-32.68 \% \mathrm{P}_{2} \mathrm{O}_{5}$; the material composition in the dark gray area was $77.12 \% \mathrm{SiO}_{2}-21.45 \% \mathrm{Al}_{2} \mathrm{O}_{3}-6.38 \% \mathrm{CaO}$; and the material composition of the light gray area was mainly $94.44 \%$ of $\mathrm{SiO}_{2}$. It can be concluded that the gray area was $\mathrm{CaO}-\mathrm{SiO}_{2}-\mathrm{P}_{2} \mathrm{O}_{5}$ solid solution phase, the dark gray area was the $\mathrm{SiO}_{2}-\mathrm{Al}_{2} \mathrm{O}_{3}-\mathrm{CaO}$ slag phase, and the light gray area was $\mathrm{SiO}_{2}$. According to the thermodynamic analysis of the reduction of phosphorus minerals, the phosphorus minerals in ores can only be reduced by solid carbon in the presence of $\mathrm{SiO}_{2}$. Therefore, the sufficient contact among phosphorus minerals, reductants, and $\mathrm{SiO}_{2}$ in ores was the necessary condition to realize the reduction of phosphorus minerals. In the coal-based reduction test, the particle size of the ore sample was generally crushed to $-2 \mathrm{~mm}$ accounts for $100 \%$. It was impossible to completely dissociate phosphorus minerals under this fineness. Therefore, some phosphorus minerals were not in contact with reductant and $\mathrm{SiO}_{2}$ in the reduction process, which resulted in that the phosphorus minerals could not be reduced and still existed in the reduced material as phosphorus minerals.

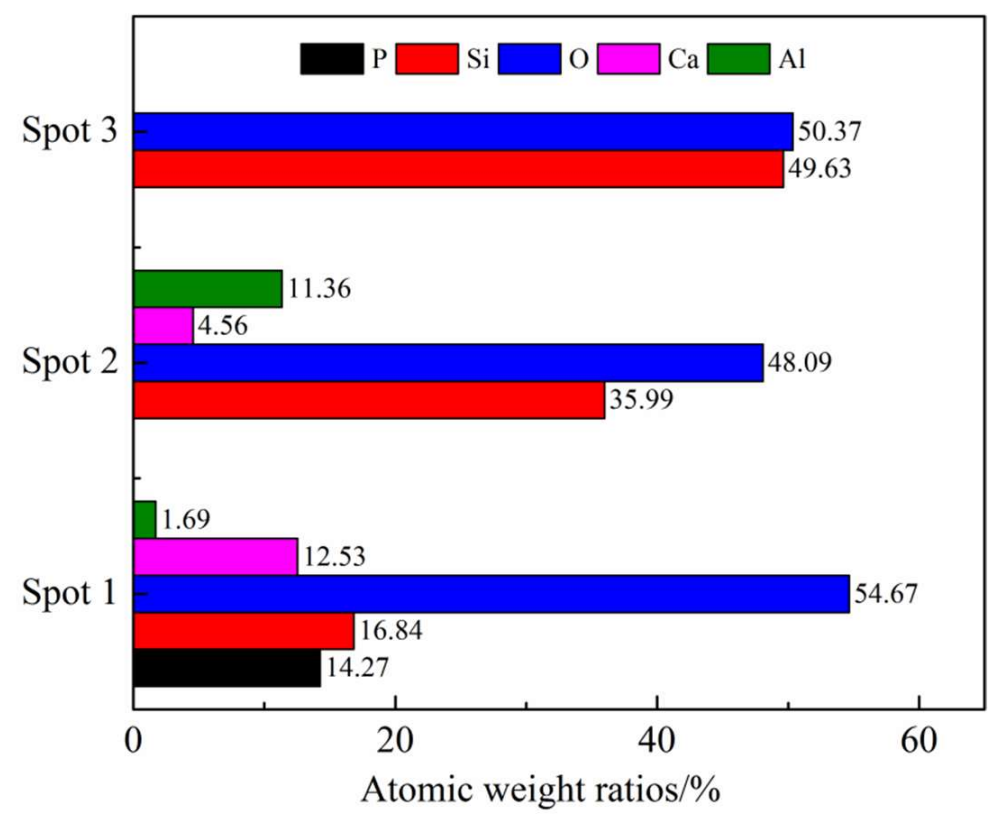

Figure 15. EDS analysis results in the slag phase of spots 1 to 3.

However, apatite was not observed in the slag phase of the reduced material under the conditions of reduction temperature $1250{ }^{\circ} \mathrm{C}$, reduction time $60 \mathrm{~min}$, and $\mathrm{C} / \mathrm{O}$ molar ratio 2.0 . The ore contained only $4.26 \%$ phosphorus minerals, and a considerable part of phosphorus minerals was reduced during the reduction process, especially when the reduction temperature was higher and the reduction time was longer, the reduction effect was better. Therefore, no apatite was found in the slag phase under this condition. In order to determine whether there was unreacted apatite in the slag phase, the slag phase was analyzed by SEM-EDS under the conditions of reduction temperature $1250{ }^{\circ} \mathrm{C}$, reduction time $20 \mathrm{~min}$, and C/O molar ratio 2.0. As shown in Figure 16, it is clearly observed that there were mainly three different substances in the slag phase. EDS spectra show that the three substances were apatite, ferrous oxide, and iron olivine, which proved that some phosphorus elements existed as apatite in the slag phase. 

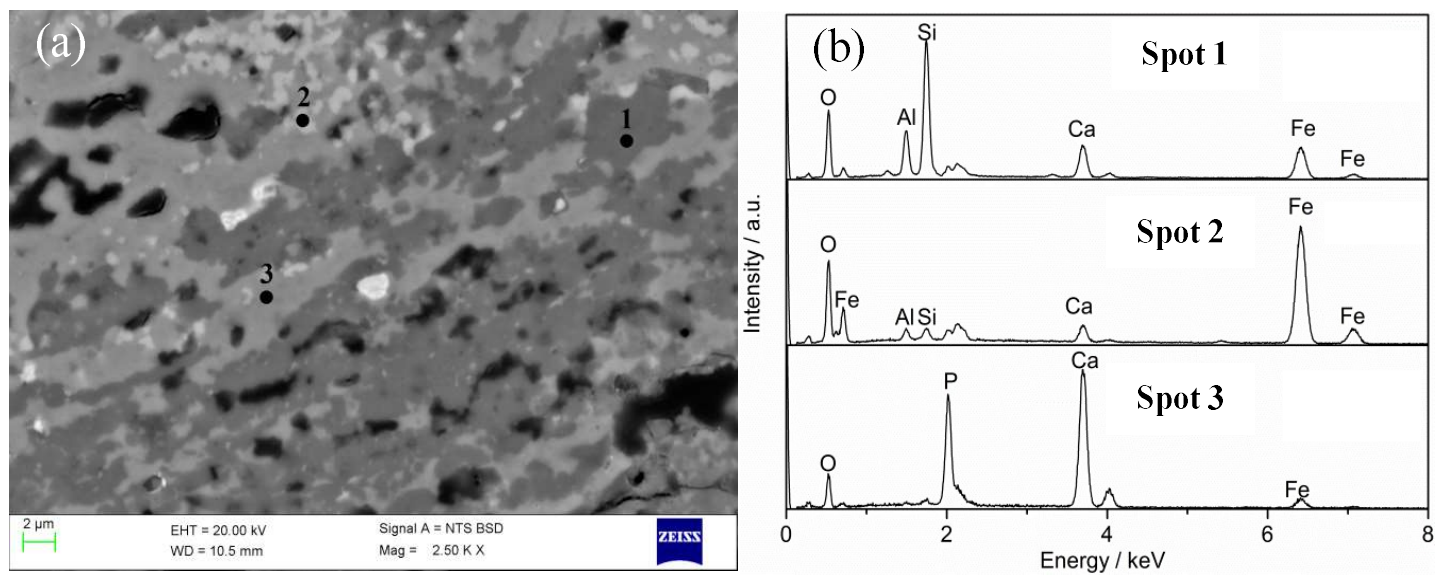

Figure 16. SEM image of slag phase and EDS analyses (reduction time of $20 \mathrm{~min}$ ): (a) SEM image and (b) EDS analyses.

Based on the above analysis, it can be concluded that there were two forms of phosphorus in the slag phase-one was unreacted apatite, and the other was $\mathrm{CaO}-\mathrm{SiO}_{2}-\mathrm{P}_{2} \mathrm{O}_{5}$ solid solution. In the early stage of coal-based reduction, phosphorus in the slag phase mainly existed in the form of apatite, while in the later stage, it mainly existed in the form of $\mathrm{CaO}-\mathrm{SiO}_{2}-\mathrm{P}_{2} \mathrm{O}_{5}$ solid solution.

\section{Conclusions}

The reduction behavior of phosphorus minerals and the existing form of phosphorus in reduced materials during the coal-based reduction of high phosphorus oolitic hematite were systematically studied using XRD, SEM-EDS, and HSC simulation software. The following conclusions were obtained: The reduction of apatite was promoted by providing the most inclined enrichment site of phosphorus (metallographic phase), while $\mathrm{Al}_{2} \mathrm{O}_{3}$ played a certain role in promoting the reduction of apatite in the presence of $\mathrm{SiO}_{2}$ after $\mathrm{Fe}_{2} \mathrm{O}_{3}$ was reduced to metal iron. Phosphorus existed mainly in two forms in the metal phase-one was in the form of $\mathrm{Fe}_{3} \mathrm{P}$ compound at the boundary of the metal phase, and the other was in the form of the solid solution in the metal iron. There were two forms of phosphorus in the slag phase- one was unreacted apatite, and the other was $\mathrm{CaO}-\mathrm{SiO}_{2}-$ $\mathrm{P}_{2} \mathrm{O}_{5}$ solid solution. In the early stage of coal-based reduction, phosphorus in the slag phase mainly existed in the form of apatite, while in the later stage, it mainly existed in the form of $\mathrm{CaO}-\mathrm{SiO}_{2}-\mathrm{P}_{2} \mathrm{O}_{5}$ solid solution.

Author Contributions: Conceptualization, J.J.; data curation, W.Z.; formal analysis, J.J.; funding acquisition, Y.S.; investigation, W.Z. and Y.H.; methodology, W.Z.; project administration, Y.S.; resources, J.J. and Y.L.; supervision, Y.H.; validation, Y.L. All authors have read and agreed to the published version of the manuscript.

Funding: National Natural Science Foundation of China: 51604063, 51874071 and 51734005. Fok Ying Tung Education Foundation for Young Teachers in the Higher Education Institutions of China: 161045. Liaoning Revitalization Talents Program: XLYC1807111. Fundamental Research Funds for the Central Universities: N180105030.

Institutional Review Board Statement: Not applicable.

Informed Consent Statement: Not applicable.

Data Availability Statement: Not applicable.

Acknowledgments: This research was funded by the National Natural Science Foundation of China (Grant No.51874071, 51734005), the Fok Ying Tung Education Foundation for Yong Teachers in the Higher Education Institutions of China (No. 161045), and the Liao Ning Revitalization Talents Program (No. XLYC1807111).

Conflicts of Interest: The authors declare no conflict of interest. 


\section{References}

1. Zhang, X.L.; Gu, X.T.; Han, Y.X.; Parra-Álvarez, N.; Claremboux, V.; Kawatra, S.K. Flotation of iron ores: A review. Min. Proc. Ext. Met. Rev. 2019, 1-29. [CrossRef]

2. Zhang, X.L.; Han, Y.X.; Sun, Y.S.; Lv, Y.; Li, Y.J.; Tang, Z.D. An novel method for iron recovery from iron ore tailings with preconcentration followed by magnetization roasting and magnetic separation. Min. Proc. Ext. Met. Rev. 2020, 2, 117-129. [CrossRef]

3. Fang, S.; Xu, L.; Wu, H.; Tian, J.; Lu, Z.; Sun, W.; Hu, Y. Adsorption of Pb (II)/benzohydroxamic acid collector complexes for ilmenite flotation. Miner. Eng. 2018, 126, 16-23. [CrossRef]

4. Sun, Y.S.; Zhu, X.R.; Han, Y.X.; Li, Y.J. Green magnetization roasting technology for refractory iron ore using siderite as a reductant. J. Clean Prod. 2019, 206, 40-50. [CrossRef]

5. Gao, P.; Li, G.F.; Han, Y.X.; Sun, Y.S. Reaction behavior of phosphorus in coal-based reduction of an oolitic hematite ore and pre-dephosphorization of reduced iron. Metals 2016, 6, 82. [CrossRef]

6. Sun, Y.S.; Zhang, Q.; Han, Y.X.; Gao, P.; Li, G.F. Comprehensive utilization of iron and phosphorus from high-phosphorus refractory iron ore. JOM 2018, 70, 144-149. [CrossRef]

7. Kang, Y. Desiliconisation and dephosphorisation behaviours of various oxygen sources in hot metal pre-treatment. Metals 2019, 2, 251. [CrossRef]

8. Mamdouh, O.; Timo, F.; Riku, M. Effect of microwave pre-treatment on the magnetic properties of iron ore and its implications on magnetic separation. Sep. Purif. Technol. 2014, 136, 223-232.

9. Delvasto, P.; Ballester, A.; Muñoz, J.A.; González, F.; Blázquez, M.L.; Igual, J.M.; Valverde, A.; García-Balboa, C. Mobilization of phosphorus from iron ore by the bacterium Burkholderia caribensis FeGL03. Min. Eng. 2009, 22, 1-9. [CrossRef]

10. Mamdouh, O.; Timo, F.; Riku, M. Influence of microwave radiation on the magnetic properties of molybdenite and arsenopyrite. Powder Technol. 2017, 15, 276-281.

11. Ionkov, K.; Gaydardzhiev, S. Amenability for processing of oolitic iron ore concentrate for phosphorus removal. Min. Eng. 2013, 46-47, 119-127. [CrossRef]

12. Cao, Y.Y.; Zhang, Y.R.; Sun, T.C. Dephosphorization behavior of high-phosphorus oolitic hematite-solid waste containing carbon briquettes during the process of direct reduction-magnetic separation. Metals 2018, 11, 897. [CrossRef]

13. Zhang, Y.Y.; Xue, Q.G.; Wang, G.; Wang, J.S. Phosphorus containing mineral evolution and thermodynamics of phosphorus vaporization during carbothermal reduction of high-phosphorus iron ore. Metals 2018, 6, 451. [CrossRef]

14. Mamdouh, O.; Timo, F.; Riku, M. XPS and FTIR spectroscopic study on microwave treated high phosphorus iron ore. Appl. Surf. Sci. 2015, 45, 127-140.

15. Xia, W.T.; Ren, Z.D.; Gao, Y.F. Removal of phosphorus from high phosphorus iron ores by selective HCl leaching method. J. Iron Steel Res. Int. 2011, 18, 1-4. [CrossRef]

16. Yuan, S.; Zhou, W.T.; Han, Y.X.; Li, Y.J. Efficient enrichment of low grade refractory rhodochrosite by preconcentration-neutral suspension roasting-magnetic separation process. Powder Technol. 2020, 361, 529-539. [CrossRef]

17. Tang, Z.D.; Gao, P.; Sun, Y.S.; Han, Y.X.; Li, E.L.; Chen, J.; Zhang, Y.H. Studies on the fluidization performance of a novel fluidized bed reactor for iron ore suspension roasting. Powder Technol. 2020, 360, 649-657. [CrossRef]

18. Zhang, H.Q.; Zhang, Z.Q.; Luo, L.Q.; Yu, H. Behavior of Fe and P during reduction magnetic roasting-separation of phosphorusrich oolitic hematite. Energ. Source. Part. A 2019, 1, 47-64. [CrossRef]

19. Sun, Y.S.; Zhou, W.T.; Han, Y.X.; Li, Y.J. Effect of different additives on reaction characteristics of fluorapatite during coal-based reduction of iron ore. Metals 2019, 9, 923. [CrossRef]

20. Sun, Y.S.; Han, Y.X.; Gao, P.; Yu, J.W. Size distribution behavior of metallic iron particles in coal-based reduction products of an oolitic iron ore. Min. Proc. Ext. Met. Rev. 2015, 36, 249-257. [CrossRef]

21. Sun, Y.S.; Li, Y.F.; Han, Y.X.; Li, Y.J. Migration behaviors and kinetics of phosphorus during coal-based reduction of highphosphorus oolitic iron ore. Int. J. Min. Met. Mater. 2019, 8, 938-945. [CrossRef]

22. Zhang, X.; Li, G.H.; Rao, M.J.; Mi, H.P.; Liang, B.J.; You, J.X.; Peng, Z.W.; Jiang, T. Growth of metallic iron particles during reductive roasting of boron-bearing magnetite concentrate. J. Cent. South. Univ. 2020, 5, 1484-1494. [CrossRef]

23. Xie, R.Q.; Zhu, Y.M.; Liu, J.; Wang, X.; Li, Y.J. Differential collecting performance of a new complex of decyloxy-propyl-amine and $\alpha$-bromododecanoic acid on flotation of spodumene and feldspar. Min. Eng. 2020, 153, 106377. [CrossRef]

24. Yang, B.; Zhu, Z.L.; Sun, H.R.; Yin, W.Z.; Hong, J.S.; Cao, S.H.; Tang, Y.; Zhao, C.; Yao, J. Improving flotation separation of apatite from dolomite using PAMS as a novel eco-friendly depressant. Min. Eng. 2020, 156, 106492. [CrossRef]

25. Liu, J.; Xie, R.Q.; Zhu, Y.M.; Li, Y.J.; Liu, C. Flotation behavior and mechanism of styrene phosphonic acid as collector on the flotation separation of fluorite from calcite. J. Mol. Liq. 2021, 115261. [CrossRef]

26. Xie, R.Q.; Zhu, Y.M.; Liu, J.; Li, Y.J. The flotation behavior and adsorption mechanism of a new cationic collector on the separation of spodumene from feldspar and quartz. Sep. Purif. Technol. 2021, 264, 118445. [CrossRef]

27. Zhou, W.T.; Sun, Y.S.; Han, Y.X.; Gao, P.; Li, Y.J. Recycling iron from oolitic hematite via microwave fluidization roasting and magnetic separation. Min. Eng. 2021, 106851.

28. Wang, N.; Liang, Z.G.; Chen, M.; Zou, Z.S. Phosphorous enrichment in molten adjusted converter slag: Part I Effect of adjusting technological conditions. J. Iron Steel. Res. Int. 2011, 18, 17-19, 39. [CrossRef]

29. Wang, N.; Liang, Z.G.; Chen, M.; Zou, Z.S. Phosphorous enrichment in molten adjusted converter slag: Part II Enrichment behavior of phosphorus in $\mathrm{CaO}-\mathrm{SiO}_{2}-\mathrm{FeO}_{x}-\mathrm{P}_{2} \mathrm{O}_{5}$ molten slag. J. Iron Steel. Res. Int. 2011, 18, 22-26. [CrossRef] 
30. Inoue, R.; Suito, H. Phosphorous partition between $2 \mathrm{CaO} \cdot \mathrm{SiO}_{2}$ particles and $2 \mathrm{CaO}-\mathrm{SiO}_{2}-\mathrm{FetO}$ slags. ISIJ Int. 2006, 46 , 174-179. [CrossRef]

31. Suito, H.; Inoue, R. Behavior of phosphorous transfer from $\mathrm{CaO}-\mathrm{Fe}_{\mathrm{t}} \mathrm{O}-\mathrm{P}_{2} \mathrm{O}_{5}\left(-\mathrm{SiO}_{2}\right)$ slag to $\mathrm{CaO}$ particles. ISIJ Int. 2006, 46, 180-187. [CrossRef]

32. Fukagai, S.; Hamamo, T.; Tsukihashi, F. Formation reaction of phosphate compound in multi phase flux at 1573 K. ISIJ Int. 2007, 47, 187-189. [CrossRef]

33. Yang, X.; Matsuura, H.; Tsukihashi, F. Condensation of $\mathrm{P}_{2} \mathrm{O}_{5}$ at the interface between $2 \mathrm{CaO} \cdot \mathrm{SiO}_{2}$ and $\mathrm{CaO}-\mathrm{SiO}_{2}-\mathrm{FeO}-\mathrm{P}_{2} \mathrm{O}_{5}$ slag. ISIJ Int. 2009, 49, 1298-1307. [CrossRef] 